\title{
Development and quality of pineapple guava fruit in two locations with different altitudes in Cundinamarca, Colombia
}

\author{
Alfonso Parra-Coronado $\left({ }^{1 *}\right)$; Gerhard Fischer $\left({ }^{2}\right)$; Jesús Hernán Camacho-Tamayo $\left({ }^{1}\right)$ \\ (') Universidad Nacional de Colombia (UNAL), Departamento de Ingeniería Civil y Agricola, Carrera 30, \\ No 45A-03, 11001, Bogotá D.C., Colombia. \\ (2) UNAL, Departamento de Agronomía, Bogotá D.C., Colombia. \\ (*) Corresponding author: aparrac@unal.edu.co
}

Received: Dec. 22, 2014; Accepted: Mar.16, 2015

\begin{abstract}
Fruit growth is stimulated by different weather conditions. The aim of this study was to determine the influence of weather conditions on the physicochemical properties of pineapple guava fruit growth. Twenty trees were marked in two production areas located at different altitudes (1,800 and 2,580 m.a.s.l.), and measurements were performed every 7 days from 99 and 141 days post-anthesis to harvest at altitudes of 1,800 and 2,580 m.a.s.l., respectively. The results indicate that altitude and weather conditions greatly influence the growth and development of pineapple guava fruit, and these effects are primarily manifested in the physical characteristics of the fruit. The weight and size of the fruit at harvest are directly related to the altitude of the production area. The weather condition that has the greatest impact on total titratable acidity at harvest is cumulative radiation during fruit growth; the highest value of total soluble solids at harvest corresponds to the location with the higher altitude, lower rainfall and relative humidity and higher cumulative radiation during the fruit growth period. The hue angle and pulp firmness at harvest are not influenced by the location or weather conditions at any location and do not determine the fruit quality at harvest time.
\end{abstract}

Key words: climate, Acca sellowiana (O. Berg) Burret, total soluble solids, titratable acidity, hue angle.

\section{INTRODUCTION}

Pineapple guava (Acca sellowiana (O. Berg) Burret; Mirtaceae) is native to South America in the areas of southern Brazil, Uruguay, upper region of western Paraguay and northeastern Argentina (Parra-Coronado \& Fischer, 2013). It is a perennial and long-lived species adapted to different climatic zones (Fischer, 2003). Under seasonal conditions in the subtropics, it produces an annual harvest, whereas in the tropics, it can produce fruit throughout the entire year (Quintero, 2012). Because of its excellent adaptation in the areas between 1,800 and 2,700 m.a.s.l., it is considered a promising crop for the Colombian Andes.

Currently, significant commercial production of pineapple guava is limited to New Zealand, Georgia, Azerbaijan, Colombia and California, although there is great interest in establishing its commercial production in Uruguay and Brazil (Parra-Coronado \& Fischer, 2013). Different varieties of pineapple guava are harvested in Colombia, and this is considered an important factor for pollination and production of quality fruit. In Colombia, Quintero (2012) estimated a production area for pineapple guava of
650 ha, and the main producing departments are Boyacá, Cundinamarca, Santander and Norte de Santander.

Similar to other plant species, pineapple guava fruits have defined growth stages between anthesis and harvest, such as cell division, tissue differentiation, increased size and maturation (Parra-Coronado et al., 2006). Growth can refer to an irreversible increase in dry weight or volume and changes in shape, size, mass, or a number of structures that are a function of genotype and the environment (Krug, 1997) and yield a quantitative increase in the size and weight of the plant or organ (Ardila et al., 2011). The study of fruit growth is useful for determining how fruit grows with respect to age and how they change in size and weight at harvest time (Avanza et al., 2008), as well as the optimal harvest conditions (Cañizares et al., 2003), cultivation practices and harvest management (Casierra \& Cardozo, 2009).

To determine fruit ripeness, which is directly related to quality, different parameters must be considered, such as skin and/or pulp firmness, total titratable acidity 
and content of total soluble solids (Parra-Coronado \& Hernández-Hernández, 2008; Parra-Coronado et al., 2006). Fruit growth and other quality parameters are influenced by weather conditions, especially light intensity and temperature (Calvo, 2004), which directly affect fruit formation, concentration of soluble solids, firmness and color (Kappel $\&$ Neilsen, 1994) and maintain quality during postharvest handling (Parra-Coronado et al., 2006).

The decrease in firmness values as the fruit grows is caused by the transformation of cementitious substances that provide fruit turgor (protopectins and pectins) into water-soluble pectic acids and other substances that produce characteristic fruit softening during the ripening process (Parra-Coronado et al., 2006). According to Gálvis et al. (2002), pulp softening is characteristic of the ripening of certain fruits and caused by several factors, including the action of hydrolase enzymes of the cell wall, which act on pectin. The enzyme responsible for the solubilization of pectin is polygalacturonase (PG), which exhibits increased activity as maturation proceeds.

PG activity in pineapple guava is greater inside the mesocarp; this suggests that softening starts from the inside to the outside (Parra-Coronado \& Fischer, 2013), which is reflected in the lower value of pulp firmness compared to skin firmness. Cellulases are also related to fruit softening, and they present low activity in green fruit but rapidly increase during maturation (Kays, 1997). Fruit firmness is a relevant characteristic for consumption quality and a factor that must be considered in the design of packaging and transportation systems during harvest and post-harvest (Parra-Coronado \& Fischer, 2013).

The investigations of pineapple guava include studies of the physicochemical characterization of fruit growth and development for clones and under certain cultivation conditions (Rodríguez et al., 2006) as well as studies of the effect of weather and cultivation conditions on the physiological or ecophysiological processes of the plant (Fischer, 2003). Thus far, few studies have been reported on the influence of weather conditions on the quality parameters during fruit growth. Therefore, this study aimed to determine the influence of weather conditions on certain quality characteristics during pineapple guava fruit growth (from anthesis to harvest) under the conditions experienced at the Colombian Andes.

\section{MATERIAL AND METHODS}

\section{Location and characterization of the study locations}

The study was conducted at two locations in the department of Cundinamarca (Colombia), and these locations were planted with pineapple guava clone 41 ('Quimba') in 2006.
Similar harvest management activities, such as pruning and fertilization, were performed at the two farms to eliminate the influence of cultivation variables. The first site is located in the town of Tenjo at $4^{\circ} 51^{\prime} 23^{\prime \prime} \mathrm{N}$ and $74^{\circ} 6^{\prime} 33^{\prime \prime}$ W at an average altitude of 2,580 m.a.s.l., and it has an average temperature of $12.5^{\circ} \mathrm{C}$, relative humidity between 74 and $86 \%$ and a bimodal rainfall regime with annual rainfall values of $765 \mathrm{~mm}$ that are concentrated in the periods from March to May and September to November. The second study site is located in the town of San Francisco de Sales at 4 ${ }^{\circ} 57^{\prime} 57^{\prime \prime} \mathrm{N}$ and $74^{\circ} 16^{\prime} 27^{\prime \prime}$ W at an average altitude of 1,800 m.a.s.l., and it has an average temperature of $20.6^{\circ} \mathrm{C}$, relative humidity between 63 and $97 \%$ and a bimodal rainfall regime with annual rainfall values of $1,493 \mathrm{~mm}$ that are concentrated in the periods from February to May and September to November.

A physicochemical characterization of the soil of the experimental plots of each farm was performed, with six samples collected per farm at a depth between 10 and $20 \mathrm{~cm}$, for a total of 12 soil samples. The characterization showed that the soils of both farms are sandy loam, and the $\mathrm{Ca} / \mathrm{Mg}$, $\mathrm{Mg} / \mathrm{K}, \mathrm{Ca} / \mathrm{K}$ and $(\mathrm{Ca}+\mathrm{Mg}) / \mathrm{K}$ ratios indicated that there are no $\mathrm{K}$ and $\mathrm{Mg}$ deficiencies and $\mathrm{Cu}$ and $\mathrm{Mn}$ values below those considered optimum.

\section{Experimental design}

Ten trees were collected per basic plot and from two plots per farm for a total of 40 trees. To study the growth variations (size and weight) of the total soluble solids (TSS), total titratable acidity (TTA), hue angle ( $\mathrm{oh}$ ) and firmness, one plot per farm and per harvest were considered. The trees under investigation were placed in the center of the cultivation plot to maintain uniformity under the weather conditions and eliminate the edge effect. Each of the plants (sample unit) was listed, and the flower buds present in the middle third of the canopy were marked to track fruit growth and development.

\section{Sampling}

Sampling was conducted in 10 trees for each plot, with random fruits collected per tree on a weekly basis. To determine fruit growth, sampling was performed from 99 days post-anthesis to harvest for the two locations, and to determine TSS, TTA, oh and fruit firmness, sampling was performed from 99 and 141 days post-anthesis to harvest for sites at San Francisco and Tenjo, respectively, when the fruits were large enough to perform the specific analysis. This procedure was performed during two consecutive years and two harvests. Because of the prevailing weather conditions during the research period, the plants under study only produced an annual harvest. 
To determine the periods of anthesis to harvest of the pineapple guava fruits (Table 1), the weather conditions of the study sites were obtained from the two farms over a two-year recording period (2012-2014). Meteorological data were obtained from automated iMETOS ECO D2 weather stations (Pessl Instruments, Weiz, Austria), which record hourly data for the temperature, rainfall, relative humidity and total radiation.

\section{Measured variables}

The following growth variables were measured in the study: variation of individual fruit fresh weight (g) using the gravimetric method and an analytical balance $(0.0001 \mathrm{~g})$; fruit equatorial diameter and length $(\mathrm{mm})$ using an electronic digital caliper to the nearest $0.01 \mathrm{~mm}$; variation of fruit skin and pulp firmness using a Brookfield CT3-4500 texture analyzer (Brookfield Engineering, Middleboro, MA, USA) with a TA39 probe and accuracy of $\pm 0.5 \%$, with two readings per fruit; TSS according to Colombian regulation NTC 4624 (ICONTEC, 1999a) using an Eclipse refractometer (Bellingham Stanley, Tunbridge Well, UK) with a scale of $0-32$ and accuracy of $0.2^{\circ} \mathrm{Brix}$; TTA according to regulation NTC 4623 (ICONTEC, 1999b); maturity ratio (MR) according to the TSS/TTA ratio; skin color (oh) using a Minolta CR-400 color meter (Konica Minolta, Ramsey, NJ, USA). The above-mentioned parameters were obtained for the fruits of each of the experimental plots. The statistical design was entirely casualized, with five replicates per test.

\section{Statistical analysis}

To analyze the behavior of each of the quality parameters and their variation over time, the statistical software IBM-SPSS v.20 (SPSS Inc., Chicago, IL, USA) was used, and a correlation analysis was performed between different fruit quality parameters using the datasets from the two different periods for cultivar and each of the study locations (one plot per harvest). The results were analyzed using descriptive statistics, and the standard deviation (SD) was the dispersion factor. Tukey's range tests were performed for fruit quality characteristics at harvest time for each of the study locations and each harvest.

\section{RESULTS AND DISCUSSION}

\section{Fruit growth}

Pineapple guava clone 41 growth ('Quimba') grows in three stages (Figure 1). The first stage is slow growth and continues for 113 and 148 days in San Francisco and Tenjo, respectively. The second stage is characterized by a period of increased growth and continues until 141 days in San Francisco and up to 166 days in Tenjo. The third stage is rapid growth that continues until physiological maturity is reached, which corresponds to the final 14 days of growth for the two locations. These results are consistent with the growth theory of fleshy fruits that have simple sigmoid growth (Salisbury \& Ross, 2000) and with reports by Rodríguez et al. (2006) for pineapple guava 41 and 8-4 clones, although the times between stages were different, which is explained by differences in the study sites (altitude) and weather conditions (Table 1).

The weight gained in the last 14 days varies between 25 and $45 \%$ with respect to the final weight for fruits produced in the town of San Francisco and between 58 and 68\% for fruits produced in the town of Tenjo. This weight behavior is similar to that of other fruits (Parra-Coronado et al., 2006) and reveals the importance of harvesting at the right time

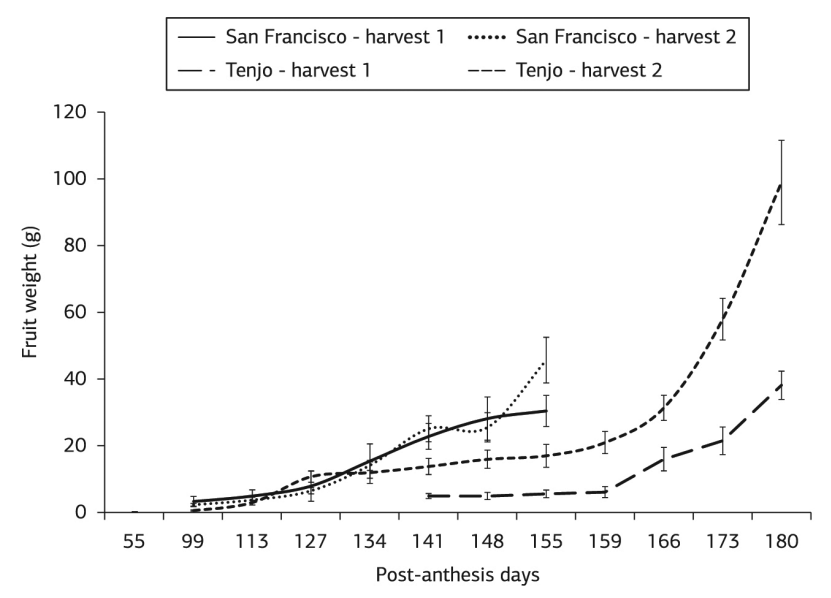

Figure 1. Pineapple guava fruit fresh weight variation in the towns of Tenjo and San Francisco de Sales. Bars show the standard deviation.

Table 1. Weather conditions in the areas during pineapple guava fruit development

\begin{tabular}{|c|c|c|c|c|c|c|c|}
\hline Location & Harvest & Days $^{1}$ & $\mathrm{GDD}^{2}\left({ }^{\circ} \mathrm{C}\right)$ & $\mathrm{T}^{3}\left({ }^{\circ} \mathrm{C}\right)$ & $\mathrm{RH}^{4}(\%)$ & $\mathrm{P}^{5}(\mathrm{~mm})$ & $\operatorname{Rad}^{6}\left[\mathrm{~W} \mathbf{m}^{-2}\right]$ \\
\hline Tenjo & 1 & 180 & 1,979 & 12.3 & 76.4 & 190 & 12,303 \\
\hline (2,580 m.a.s.I.) & 2 & 180 & 1,966 & 12.3 & 84.3 & 417 & 9,861 \\
\hline San Francisco & 1 & 155 & 2,728 & 18.5 & 86.1 & 573 & 7,814 \\
\hline (1,800 m.a.s.l.) & 2 & 155 & 2,627 & 18.0 & 95.1 & 1,400 & 10,021 \\
\hline
\end{tabular}

${ }^{1}$ Days: calendar days from anthesis to harvest. ${ }^{2} \mathrm{GDD}$ : accumulated growing degree-days from anthesis to harvest. ${ }^{3} \mathrm{~T}$ : average temperature during the study period. ${ }^{4} \mathrm{RH}$ : average relative humidity during the study period. ${ }^{5} \mathrm{P}$ : cumulative rainfall from anthesis to harvest. ${ }^{6} \mathrm{Rad}$ : cumulative radiation from anthesis to harvest. 
because yields would be lower with an early harvest, which would affect the income of farmers.

The results obtained in this investigation indicate that the fruits produced at higher temperatures $\left(18^{\circ} \mathrm{C}\right.$ in San Francisco) grow and develop faster and require fewer calendar days from anthesis to harvest, which is consistent with the findings for tomatoes (Gruda, 2005) and cape gooseberry (Physalis peruviana) (Fischer et al., 2007).

Figure 1 shows that the weight of pineapple guava fruits at harvest is higher in fruits produced at higher altitudes (Tenjo) where the cumulative radiation is greater, and a greater number of calendar days and less thermal time (GDD) is required from anthesis to harvest (Table 1). These results are consistent with those observed by Regina et al. (2010) for 'Chardonnay' and 'Pinot Noir' grape cultivars grown in the state of Minas Gerais (Brazil), which have a larger size and fresh mass at 1,150 m.a.s.l. than those grown at 873 m.a.s.l. In addition, Fischer et al. (2007) observed longer fruit development in cape gooseberry at 2,690 m.a.s.l. (75 days) compared with 2,300 m.a.s.l. (66 days), which was associated with lower temperatures at higher altitude. Martínez-Vega et al. (2008) found similar results for pineapple guava fruits of clone 41 and indicated that the fruits with the lowest fresh weight values were located in the inner core of the canopy, which has a low incidence of light radiation, thus supporting light radiation as "the luminosity factor essential for proper photosynthesis and the production of photoassimilates for fruit development."

The lower weight and size of the fruits produced under low light intensity (Figure 1), which is reflected in the lower cumulative radiation during periods of low light (Table 1), has also been reported in strawberries (Caruso et al., 2004), 'Kensington' mangos (Léchaudel $\&$ Joas, 2007), apples (Nilsson \& Gustavsson, 2007) and plums (Murray et al., 2005). The larger fresh fruit weight at higher altitudes could be explained by the higher transpiration rate related to higher irradiance, which would provide a prolonged influx of water and nutrients to the fruit (Murray et al., 2005; Naizaque et al., 2014), suggesting that increased light availability increases and extends the xylem transport stream to these organs (Martínez-Vega et al., 2008). In addition, fruits exposed to full light usually reach a larger size. Pineapple guava is an "evergreen" fruit; therefore, its chlorophyll content and photosynthetic and carbohydrate production capacity is important (Gariglio et al., 2007). In addition, photosynthesis in the adjoining leaves near fruit that grow under good lighting is promoted by the attraction of photoassimilates of the fruit (Fischer et al., 2012).

At sites with the highest accumulated rainfall (Tenjo-2 with $417 \mathrm{~mm}$ and San Francisco-2 with 1,400 mm) and higher average relative humidity (Table 1 ), fruits with a greater weight were produced for the same location, and these rainfall amounts were similar to the amounts reported by Fischer (2003), who indicated that a commercial pineapple guava plantation requires between 700 and $1,200 \mathrm{~mm}$ of annual rainfall (and tolerates up to 2,000 $\mathrm{mm}$ ) to ensure ongoing pineapple guava production and good quality. Moreover, in experiments performed in Granada cultivars with different levels of water deficit, Galindo et al. (2014) found that plant fruits showed decreased weight during water deficits, with lower weights for higher deficits. Gruda (2005) indicated that for tomatoes grown in a range of 30 to $90 \%$ relative humidity, the fruit weight was higher in conditions of higher relative humidity.

\section{Skin and pulp firmness}

Skin and pulp firmness of pineapple guava fruit show the same behavior tendencies over time, with high values at the beginning of the analysis and decreasing values as the fruit develops (Figure 2). Skin firmness is always greater than that of the pulp for the same calendar time, with mean baseline values of $30.3 \pm 5 \mathrm{~N}$ in San Francisco and $34.0 \pm 6.6 \mathrm{~N}$ in Tenjo, which decrease as the fruit grows and reaching values at harvest of $15.2 \pm 1.6 \mathrm{~N}$ in San Francisco and 12.5 $\pm 3.0 \mathrm{~N}$ in Tenjo. Pulp firmness had mean initial values of 19.2 $\pm 3.0 \mathrm{~N}$ in San Francisco and 20.1 $\pm 5.9 \mathrm{~N}$ in Tenjo, which decrease as the fruit grows and reach values at harvest of $5.8 \pm 2.0 \mathrm{~N}$ in San Francisco and 6.6 $\pm 2.8 \mathrm{~N}$ in Tenjo. Firmness behavior with pineapple guava fruit growth is consistent with what has been reported for other products, such as pear (Parra-Coronado et al., 2006).

The skin firmness of pineapple guava fruits at harvest time is lower for fruits produced at higher altitudes (Tenjo), which provides a lower average temperature, greater cumulative radiation, greater number of calendar days and less GDD

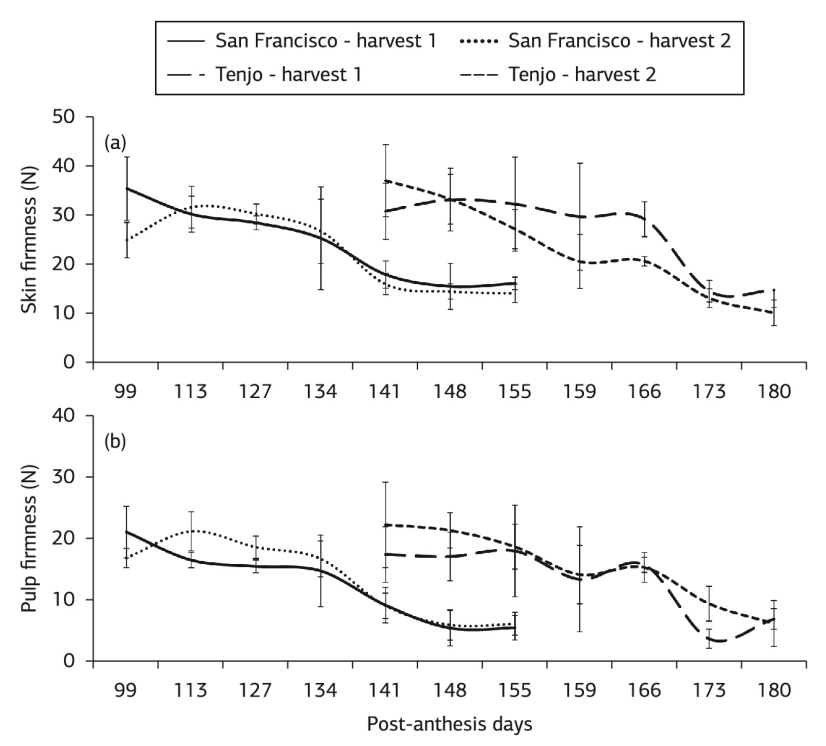

Figure 2. Pineapple guava fruit firmness variation in the towns of Tenjo and San Francisco de Sales. (a) skin firmness; (b) pulp firmness. Bars show the standard deviation. 
between anthesis and harvest (Table 1). These results are consistent with what was observed by Kang et al. (2002), who reported greater firmness for cohombro (cucumber) produced at higher temperatures, and with those reported by Murray et al. (2005), who suggested that prunes produced under low light intensity had higher firmness values.

In harvests with the highest accumulated rainfall (Tenjo-2 with $417 \mathrm{~mm}$ and San Francisco-2 with 1,400 mm) and higher average relative humidity, fruits were produced with less skin firmness for the same location; however, pulp firmness showed no differences between the two locations (Table 2). Gariglio et al. (2007) reported that high relative humidity can seriously affect fruit quality; this is the case with mandarins, which quickly lose their consistency under high relative humidity.

\section{Content of total soluble solids and total titratable acidity}

TSS and TTA of pineapple guava fruit showed an increasing trend over time (Figure 3). The variations in TSS were not significant between the beginning and end of the observations, with mean values of $10.8 \pm 0.6^{\circ}$ Brix at 113 days post-anthesis in San Francisco and $10.6 \pm 0.9^{\circ}$ Brix at 141 days post-anthesis in Tenjo. The TSS values increased with fruit growth and reached values at harvest of $11.4 \pm 0.8^{\circ} \mathrm{Brix}$ in San Francisco and 12.6 $\pm 0.8^{\circ}$ Brix in Tenjo. TTA showed mean initial values of $1.1 \pm 0.07 \%$ in San Francisco and $1.0 \pm 0.09 \%$ in Tenjo, and the values increased with fruit growth and reached values at harvest of $176 \pm 0.07 \%$ in San Francisco and $1.80 \pm 0.11 \%$ in Tenjo.

The MR is defined as the TSS/TTA ratio, and it showed a decreasing trend with fruit growth, which is inconsistent with the behavior of most fruits in which MR increases. This behavior is caused by the increase of TSS and TTA during pineapple guava fruit growth, and it indicates that the translocation of organic acids to the fruits is performed at a higher rate compared with that of TSS, which is contrary to what occurs in other fruits, in which TSS increase and TTA decreases (Parra-Coronado et al., 2006). The MR value showed mean initial values of $11.4 \pm 0.9$ in San Francisco and $10.8 \pm 1.3$ in Tenjo, and it decreased with fruit growth, reaching values at harvest of $6.5 \pm 0.7$ in San Francisco and $7.0 \pm 0.7$ in Tenjo.

The behavior of TSS and TTA during pineapple guava fruit grows is consistent with what was found by Rodríguez et al. (2006), who reported increases in both TSS and TTA during the last stage of development of pineapple guava fruit clones 41 and 8-4. In addition, there was concordance in the decrease of TSS one week before reaching physiological maturity, which is explained by the increased fruit metabolism caused by a significant increase in fresh weight, especially in fruit from the town of Tenjo. The variation of TSS and TTA is also consistent with what has been reported by Mercado-Silva et al. (1998) for guavas.
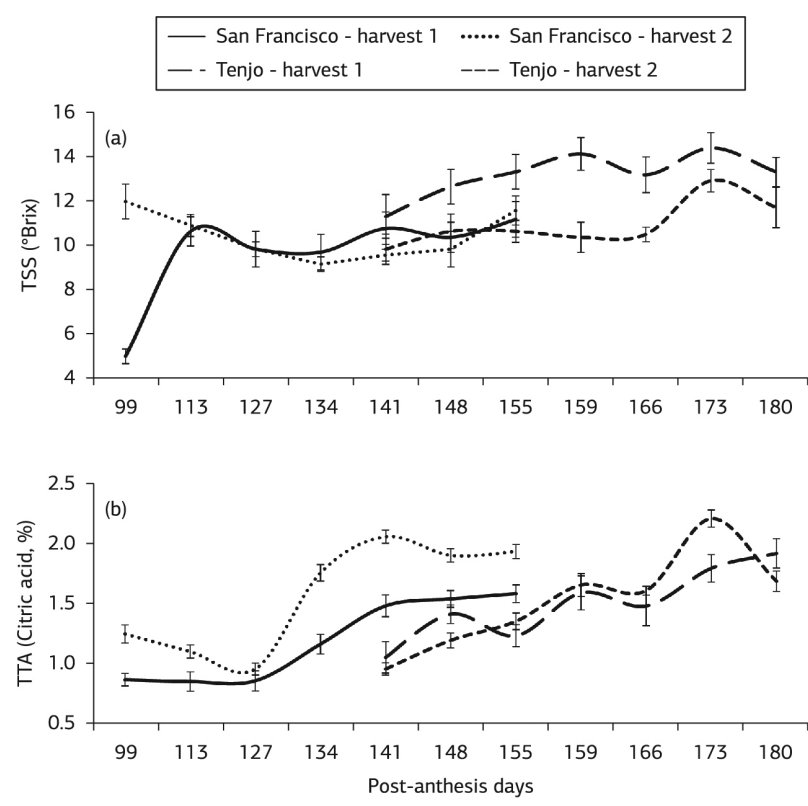

Figure 3. (a) Variation of the contents of total soluble solids ( $\left.{ }^{\circ} \mathrm{Brix}\right)$; (b) Pineapple guava fruit total titratable acidity variation (\% citric acid) in the towns of Tenjo and San Francisco de Sales. Bars show standard deviation.

Table 2. Mean values ${ }^{1}$ of pineapple guava fruit characteristics at harvest time

\begin{tabular}{|ccccc|}
\hline Parameter & \multicolumn{4}{c}{ Location - Harvest } \\
\cline { 2 - 5 } & Tenjo-1 & Tenjo-2 & San Francisco-1 & San Francisco-2 \\
\hline Fresh weight $(\mathrm{g})$ & $38.23 \pm 4.23 \mathrm{bc}$ & $98.93 \pm 12.62 \mathrm{a}$ & $30.53 \pm 4.67 \mathrm{c}$ & $45.73 \pm 6.83 \mathrm{c}$ \\
\hline Length $(\mathrm{mm})$ & $64.70 \pm 2.21 \mathrm{c}$ & $76.19 \pm 3.25 \mathrm{a}$ & $57.35 \pm 3.29 \mathrm{c}$ & $59.24 \pm 4.57 \mathrm{c}$ \\
\hline Diameter $(\mathrm{mm})$ & $35.17 \pm 1.40 \mathrm{c}$ & $49.07 \pm 2.45 \mathrm{a}$ & $32.49 \pm 2.57 \mathrm{~d}$ & $40.04 \pm 1.93 \mathrm{c}$ \\
\hline TSS $\left({ }^{\circ}\right.$ Brix) & $13.35 \pm 0.66 \mathrm{a}$ & $11.73 \pm 0.91 \mathrm{c}$ & $11.19 \pm 0.81 \mathrm{c}$ & $11.59 \pm 0.66 \mathrm{c}$ \\
\hline TTA (citric acid, \%) & $1.91 \pm 0.12 \mathrm{a}$ & $1.68 \pm 0.09 \mathrm{c}$ & $1.58 \pm 0.07 \mathrm{c}$ & $1.93 \pm 0.06 \mathrm{a}$ \\
\hline Hue angle $($ oh) & $124.72 \pm 0.75 \mathrm{a}$ & $123.63 \pm 1.35 \mathrm{a}$ & $121.63 \pm 2.53 \mathrm{a}$ & $124.16 \pm 1.36 \mathrm{a}$ \\
\hline Skin firmness $(\mathrm{N})$ & $14.82 \pm 3.51 \mathrm{a}$ & $10.21 \pm 2.64 \mathrm{c}$ & $16.20 \pm 1.30 \mathrm{a}$ & $14.18 \pm 1.87 \mathrm{a}$ \\
\hline Pulp firmness $(\mathrm{N})$ & $6.90 \pm 2.13 \mathrm{a}$ & $6.14 \pm 4.03 \mathrm{a}$ & $5.47 \pm 2.08 \mathrm{a}$ & $6.12 \pm 1.89 \mathrm{a}$ \\
\hline
\end{tabular}

${ }^{1}$ Mean \pm SD. Means followed by different letters for the same parameter indicate significant differences according to Tukey's test ( $\mathrm{p} \leq 0.05$ ). 
The TSS value of pineapple guava fruits at harvest time is greater for fruits produced at higher altitudes (Tenjo), higher cumulative radiation and lower average temperature and relative humidity (Table 1). These results are consistent with those reported by Benkeblia \& Tennant (2011), who indicated that weight, TSS and TTA were higher for different fruits grown at low temperatures. Kano (2004) indicated that at higher temperatures, the content of TSS in watermelon fruit was lower. Gruda (2005) indicated that at higher temperatures and lower relative humidity and light intensity, the content of TSS in tomato fruit was lower. However, Fischer et al. (2007) found a higher content of TSS and sucrose in cape gooseberries grown at 2,300 m.a.s.l. $\left(17.4^{\circ} \mathrm{C}\right.$ and $\left.1,294 \mathrm{~mW} \mathrm{~m}^{-2}\right)$ compared with those at 2,690 m.a.s.l. $\left(12.5^{\circ} \mathrm{C}\right.$ and $\left.1,399 \mathrm{~mW} \mathrm{~m}^{-2}\right)$; thus, the cardinal temperatures for the growth of different fruit species should be considered.

Martínez-Vega et al. (2008) found similar results for cumulative radiation for pineapple guava clone 41 fruits and indicated that fruits with the lowest TSS values were located in the inner half of the canopy, where there is a low incidence of light radiation. Similarly, the same effect of light intensity is reported for TSS in plums (Murray et al., 2005), strawberries (Caruso et al., 2004), 'Kensington' mangos (Léchaudel \& Joas, 2007) and apples (Nilsson \& Gustavsson, 2007). The TTA values of pineapple guava fruits at harvest time were not influenced by weather conditions in the two locations, which is consistent with observations in cape gooseberry grown at 2,300 and 2,690 m.a.s.l. (Fischer et al., 2007). However, Martínez-Vega et al. (2008) found that TTA in pineapple guava fruits increased slightly in the less illuminated sections of the canopy. Nuncio-Jáuregui et al. (2014) observed that in fruits of Granada, the position on the tree had no significant effect on TSS and TTA, which shows that the fruits exposed to sunlight have similar chemical compositions as the fruits exposed to shade.

\section{Color change}

Color changes occur by chlorophyll degradation and the synthesis of pigments such as anthocyanins and carotenoids (Mercado-Silva et al., 1998). The color, measured as the ${ }^{\circ} \mathrm{h}$, represents the color or hue, and it varies from $0^{\circ}$ for pure red color to $180^{\circ}$ for pure green color (Hernández et al., 2007).

The ${ }^{\circ} \mathrm{h}$ of pineapple guava fruits showed no clear trend in behavior over time (Figure 4), and it remained a green fruit with small increases in value for the two locations. The oh showed initial mean values of $125.0 \pm 2.2 \mathrm{oh}$ and harvest values of $122.9 \pm 2.0$ oh in San Francisco. In Tenjo, the $\mathrm{oh}$ showed initial mean values of $125.0 \pm 2.1 \mathrm{~h}$ and harvest values of $124.2 \pm 1.1 \mathrm{oh}$.

The unclear trend of $\mathrm{h}$ in pineapple guava fruit is consistent with what has been reported by East et al. (2009), who suggested that it is not possible to observe significant changes in skin color

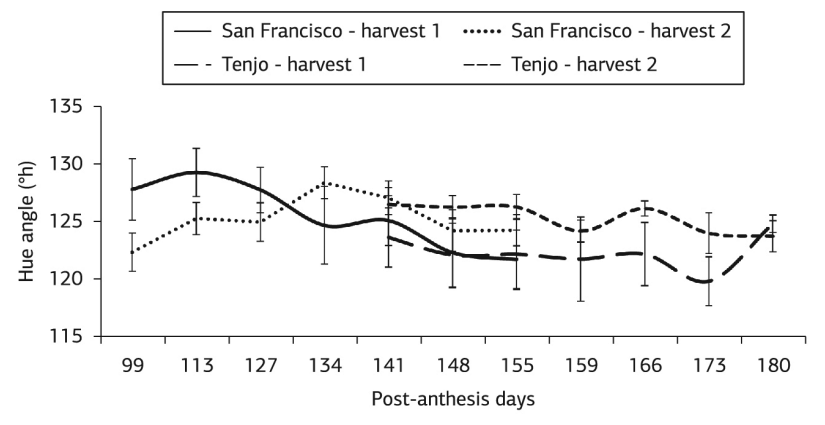

Figure 4. Pineapple guava fruit hue angle variation $\left({ }^{\circ} \mathrm{h}\right)$ in the towns of Tenjo and San Francisco de Sales. Bars show the standard deviation.

in certain cultivars during fruit ripening. In other pineapple guava cultivars, the $\mathrm{oh}$ decreased, representing a loss of green color (Velho et al., 2011). Increasing temperature promotes maturation, chlorophyll degradation and oh reduction in pineapple guava skin (Amarante et al., 2008), which does not change color because of the genetics of the fruit and only varies within a green color hue. The non-significant changes in the oh value of pineapple guava fruit for the different locations and harvests cannot be used to establish the influence of weather conditions on this color parameter.

\section{Correlation analysis}

A correlation analysis showed that as the fresh weight of pineapple guava fruit increases, so does its length $(\mathrm{r}=0.91)$, diameter $(r=0.93)$, TTA $(r=0.62)$ and TSS $(r=0.19)$, whereas a decrease is observed in skin firmness $(r=-0.76)$, pulp firmness $(\mathrm{r}=-0.64)$ and $\mathrm{oh}(\mathrm{r}=-0.13)$, which is consistent with what has been reported for pineapple guava fruits (Rodríguez et al., 2006; Velho et al., 2011), guava (Mercado-Silva et al., 1998) and pear (Parra-Coronado et al., 2006).

\section{Physicochemical characteristics at harvest}

An analysis of variance (ANOVA) showed statistical differences between locations and harvests (Table 2) for weight, diameter and length, indicating that the values of these parameters at harvest are heavily influenced by the weather conditions recorded at each location and each harvest during fruit growth (Fischer et al., 2007; Martínez-Vega et al., 2008; Regina et al., 2010).

The TTA showed statistical differences for the harvests at each location (Table 2); however, no differences were observed between the first Tenjo harvest and second San Francisco harvest and between the second Tenjo harvest and first San Francisco harvest, indicating that the weather condition that had the greatest impact on TTA at harvest was likely cumulative radiation during fruit growth (Table 1) (Fischer et al., 2007; Martínez-Vega et al., 2008). 
As for TSS, the first Tenjo harvest showed statistical differences with the San Francisco harvests and second Tenjo harvest (Table 2). In the first Tenjo harvest, the highest values for TSS were recorded, which corresponded to the lowest records of rainfall and relative humidity and highest accumulated radiation during the fruit growth period (Table 1) (Fischer et al., 2007; Léchaudel \& Joas, 2007; Benkeblia \& Tennant, 2011).

With regard to skin firmness, the second Tenjo harvest showed statistical differences with the San Francisco harvests and first Tenjo harvest (Table 2). The second Tenjo harvest had the lowest value for skin firmness; however, there was no clear influence of the weather conditions recorded during the fruit growth period (Table 1) that would explain this behavior at harvest (Kang et al., 2002; Murray et al., 2005).

The ANOVA showed no statistical differences between the locations and harvests for ${ }^{\circ} \mathrm{h}$ and pulp firmness (Table 2), indicating that the values of these parameters at harvest is not influenced by the weather conditions during fruit growth recorded for each location and each harvest and indicate that these parameters may not be determinants of quality at harvest time.

\section{CONCLUSION}

The results obtained in this study show that weather conditions (temperature, rainfall, relative humidity and radiation) and altitude have a great influence on the growth and development of pineapple guava fruit, and the effects are primarily manifested in the fruit's physical characteristics (fresh weight, length and diameter). The fruits produced at higher altitudes required a greater number of calendar days and less GDD from anthesis to harvest.

The weight, size, TTA and SST pineapple guava fruit at harvest time, have a direct relationship with the altitude of the production area. Inverse behavior was observed for the hue angle and firmness. However TSS and hue angle, are not relevant parameters of fruit quality at harvest

Thus far, there has been a lack of studies on pineapple guava, and this has prevented a greater understanding of the influence of weather conditions on the fruit's quality parameters during fruit growth. This is the first research study conducted on this subject, and we recommend further studies using a wide range of pineapple guava varieties grown in different environment.

\section{ACKNOWLEDGEMENTS}

We would like to thank the Faculty of Agricultural Sciences, Universidad Nacional de Colombia at Bogotá, for financial support and Dr. Celso Garcia Dominguez, professor of the Faculty of Agricultural Sciences, and biologist Omar Camilo Quintero for their valuable support and provision of equipment and products for the development of this research.

\section{REFERENCES}

Amarante, C. V. T., Steffens, C. A., Ducroquet, J. P. H. J., \& Sasso, A. (2008). Qualidade de goiaba-serrana em resposta à temperatura de armazenamento e ao tratamento com 1-metilciclopropeno. Pesquisa Agropecuaria Brasileira, 43, 1683-1689. http://dx.doi.org/10.1590/ S0100-204X2008001200007.

Ardila, G., Fischer, G., \& Balaguera López, H. E. (2011). Caracterización del crecimiento del fruto y producción de tres híbridos de tomate (Solanum lycopersicum L.) en tiempo fisiológico bajo invernadero. Revista Colombiana de Ciencias Hortícolas, 5, 44-56. http://dx.doi. org/10.17584/rcch.2011v5i1.1252.

Avanza, M. M., Bramardi, S. J., \& Mazza, S. M. (2008). Statistical models to describe the fruit growth pattern in sweet orange 'Valencia late'. Spanish Journal of Agricultural Research, 6, 577-585. http://dx.doi. org/10.5424/sjar/2008064-352.

Benkeblia, N., \& Tennant, P. F. (2011). Preharvest and harvest factors influencing the postharvest quality of tropical and subtropical fruits. In E. M. Yahia (Ed.), Postharvest biology and technology of tropical and subtropical fruits (Fundamental Issues, 1, p. 112-141). Cambridge: Woodhead Publishing.

Calvo, G. (2004). Efecto del 1-metilciclopropeno (1-MCP) en pera variedad Williams cosechadas con dos estados de madurez. Revista de Investigaciones Agropecuarias, 33, 3-26.

Cañizares, A., Laverde, D., \& Puesme, R. (2003). Crecimiento y desarrollo del fruto de guayaba (Psidium guajava L.) en Santa Bárbara, Estado Monagas, Venezuela. Revista UDO Agrícola, 3, 34-38.

Caruso, G., Villari, A., \& Villari, G. (2004). Quality characteristics of "Fragaria vesca L." fruits influenced by NFT solution EC and shading. Acta Horticulturae, 648, 167-174.

Casierra, F., \& Cardozo, M.C. (2009). Análisis básico del crecimiento en frutos de tomate (Lycopersicon esculentum Mill. cv. Quindío) cultivado a campo abierto. Revista Facultad Nacional de Agronomía, 62, 4815-4822.

East, A. R., Araya, X. I. T., Hertog, M. L. A. T. M., Nicholson, S. E., \& Mawson, A. J. (2009). The effect of controlled atmospheres on respiration and rate of quality change in "Unique" feiojoa fruit. Postharvest Biology and Technology, 53, 66-71. http://dx.doi.org/10.1016/j. postharvbio.2009.02.002.

Fischer, G. (2003). Ecofisiología, crecimiento y desarrollo de la feijoa. In G. Fischer, D. Miranda, G. Cayón, \& M. Mazorra (Eds.), Cultivo, poscosecha y exportación de la feijoa (Acca sellowiana Berg) (p. 9-26). Bogotá: Produmedios.

Fischer, G., Almanza-Merchán, P. J., \& Ramírez, F. (2012). Source-sink relationships in fruit species. A review. Revista Colombiana Ciencias Hortícolas, 6, 238-253. http://dx.doi.org/10.17584/rcch.2012v6i2.1980.

Fischer, G., Ebert, G., \& Lüdders, P. (2007). Production, seeds and carbohydrate contents of cape gooseberry (Physalis peruviana L.) fruits grown at two contrasting Colombian altitudes. Journal of Applied Botany and Food Quality, 81, 29-35. 
Galindo, A., Rodríguez, P., Collado-González, J., Cruz, Z. N., Torrecillas, E., Ondoño, S., Corell, M., Moriana, A., \& Torrecillas, A. (2014). Rainfall intensifies fruit peel cracking in water stressed pomegranate trees. Agricultural and Forest Meteorology, 194, 29-35. http://dx.doi. org/10.1016/j.agrformet.2014.03.015.

Gálvis, J. A., Arjona, H., Fischer, G., Landwehr, T., \& Martínez, R. (2002). Influencia de la temperatura y el tiempo de almacenamiento en la conservación del fruto de Mango (Mangifera indica L.) variedad Van Dyke. Agronomía Colombiana, 19, 23-36.

Gariglio, N. F., Pilatti, R. A., \& Agustí, M. (2007). Requerimientos ecofisiológicos de los árboles frutales. In G. O. Sozzi (Ed.), Árboles frutales: ecofisiologia, cultivo y aprovechamiento (p. 41-82). Buenos Aires: Facultad de Agronomía, Universidad de Buenes Aires.

Gruda, N. (2005). Impact of environmental factors on product quality of greenhouse vegetables for fresh consumption. Critical Reviews in Plant Sciences, 24, 227-247. http://dx.doi.org/10.1080/07352680591008628.

Hernández, M. S., Martínez, O., \& Fernández-Trujillo, J. P. (2007). Behavior of Arazá (Eugenia stipitata Mc Vaugh) fruit quality traits during growth, development and ripening. Scientia Horticulturae, 111, 220 227. http://dx.doi.org/10.1016/j.scienta.2006.10.029.

Instituto Colombiano de Normas Técnicas y Certificación - ICONTEC. (1999a). Norma técnica colombiana NTC 4624. Jugos de frutas y hortalizas. Determinación del contenido de sólidos solubles. Método refractométrico. Bogotá.

Instituto Colombiano de Normas Técnicas y Certificación - ICONTEC. (1999b). Norma técnica colombiana NTC 4623. Productos de frutas y verduras. Determinación de la acidez titulable. Bogotá.

Kang, H. M., Park, K. W., \& Saltveit, M. E. (2002). Elevated growing temperatures during the day improve the postharvest chilling tolerance of greenhouse-grown cucumber (Cucumis sativus) fruit. Postharvest Biology and Technology, 24, 49-57. http://dx.doi.org/10.1016/S09255214(01)00129-6.

Kano, Y. (2004). Effects of summer day-time temperature on sugar content in several portions of watermelon fruit (Citrullus lanatus). The Journal of Horticultural Science \& Biotechnology, 79, 142-145.

Kappel, F., \& Neilsen, G. H. (1994). Relationship between light microclimate, fruit growth, fruit quality, specific leaf weight and $\mathrm{N}$ and $\mathrm{P}$ content of spur leaves of 'Bartlett' and 'Anjou' pear. Scientia Horticulturae, 59, 187-196. http://dx.doi.org/10.1016/0304-4238(94)90012-4.

Kays, S.(1997). Postharvest physiology of perishable plant products. Athens: Exxon Press.

Krug, H. (1997). Enviromental influences on development growth and yield. In H. C. Wien (Ed.), The physiology of vegetable crops (p. 101-180). London: Cabi Publishing.

Léchaudel, M., \& Joas, J. (2007). An overview of preharvest factors influencing mango fruit growth, quality and postharvest behaviour. Brazilian Journal of Plant Physiology, 19, 287-298. http://dx.doi. org/10.1590/S1677-04202007000400004.

Martínez-Vega, R. R., Fischer, G., Herrera, A., Chaves, B., \& Quintero, O. C. (2008). Características físico-químicas de frutos de feijoa influenciadas por la posición en el canopi. Revista Colombiana de Ciencias Hortícolas, 2, 21-32. http://dx.doi.org/10.17584/rcch.2008v2i1.1170.
Mercado-Silva, E., Bautista, P. B., \& Garcia-Velasco, M. A. (1998). Fruit development, harvest index and ripening changes of guavas produced in Central Mexico. Postharvest Biology and Technology, 13, 143-150. http://dx.doi.org/10.1016/S0925-5214(98)00003-9.

Murray, X. J., Holcroft, D. M., Cook, N. C., \& Wand, S. J. E. (2005). Postharvest quality of 'Laetitia' and 'Songold' (Prunus salicina Lindell) plums as affected by preharvest shading treatments. Postharvest Biology and Technology, 37, 81-92. http://dx.doi.org/10.1016/j. postharvbio.2005.02.014.

Naizaque, J., García, G., Fischer, G., Melgarejo, L.M. (2014). Relación entre la densidad estomática, la transpiración y las condiciones ambientales en feijoa (Acca sellowiana (O. Berg) Burret). Revista UDCA: Actualidad y Divulgación Científica, 17, 115-121.

Nilsson, T., \& Gustavsson, K. E. (2007). Postharvest physiology of 'Aroma' apples in relation to position on the tree. Postharvest Biology and Technology, 43, 36-46. http://dx.doi.org/10.1016/j.postharvbio.2006.07.011.

Nuncio-Jáuregui, N., Calín-Sánchez, A., Carbonell-Barrachina, A., \& Hernández, F. (2014). Changes in quality parameters, proline, antioxidant activity and color of pomegranate (Punica granatum L.) as affected by fruit position within tree, cultivar and ripening stage. Scientia Horticulturae, 165, 181-189. http://dx.doi.org/10.1016/j.scienta.2013.11.021.

Parra-Coronado, A., \& Fischer, G. (2013). Maduración y comportamiento poscosecha de la feijoa (Acca sellowiana (O. Berg) Burret). Una revisión. Revista Colombiana de Ciencias Hortícolas, 7, 98-110. http://dx.doi. org/10.17584/rcch.2013v7i1.2039.

Parra-Coronado, A., \& Hernández-Hernández, J. E. (2008). Fisiología postcosecha de frutas y hortalizas (4. ed.). Bogotá: Facultad de Ingeniería, Universidad Nacional de Colombia.

Parra-Coronado, A., Hernández-Hernández, J. E., \& Camacho-Tamayo, J. H. (2006). Estudio de algunas propiedades físicas y fisiológicas precosecha de la pera variedad Triunfo de Viena. Revista Brasileira de Fruticultura, 28, 55-59. http://dx.doi.org/10.1590/S0100-29452006000100017.

Quintero, O. C. (2012). Feijoa (Acca sellowiana Berg). In G. Fischer (Ed.), Manual para el cultivo de frutales en el trópico (p. 443-473). Bogotá: Produmedios.

Regina, M. A., Carmo, E. L., Fonseca, A. R., Purgatto, E., Shiga, T. M., Lajolo, F. M., Ribeiro, A. P., \& Mota, R. V. (2010). Influência da altitude na qualidade das uvas 'Chardonnay' e 'Pinot Noir' em Minas Gerais. Revista Brasileira de Fruticultura, 32, 143-150. http://dx.doi. org/10.1590/S0100-29452010005000023.

Rodríguez, M., Arjona, H. E., \& Campos, H. A. (2006). Caracterización fisicoquímica del crecimiento y desarrollo de los frutos de feioja (Acca sellowiana Berg) en los clones 41 (Quimba) y 8-4. Agronomía Colombiana, 24, 54-61.

Salisbury, F. B., \& Ross, C. W. (2000). Fisiología de las plantas 3: desarrollo de las plantas y fisiología ambiental. (p. 527-564). Madrid: Thompson Editores Spain, Paraninfo S.A.

Velho, A. C., Amarante, C. V. T., Argenta, L. C., \& Steffens, C. A. (2011). Influência da temperatura de armazenamento na qualidade pós-colheita de goiabas serranas. Revista Brasileira de Fruticultura, 33, 14-20. http:// dx.doi.org/10.1590/S0100-29452011005000016. 